\title{
低気圧インパルス放電によるアーク 開始時間と陰極表面の影響
}

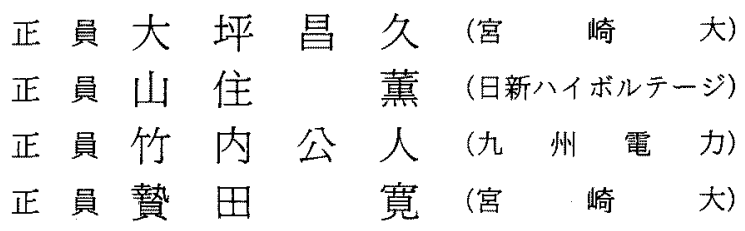

\section{Arc Occurrence Time and Influence of Cathode Surface by Impulse Discharges at Low Pressure in Air \\ Niasahisa Otsubo, Member (Miyazaki University), Kaoru Yamasumi, Member (Nissin High Voltage Co., Ltd.), Kimito Takeuchi, Member (Kyushu Electric Power Co., Inc.), Hiroshi Nieda, Member (Miyazaki University)}

The time interval from voltage application to the arc occurrence in the impulse discharge process of a positive point to plane configuration having a protrusion on the plane was measured in air at low pressure. The time was compared with one in the configuration without protrusion under the same conditions. Simultaneously with the measurements of the time, the luminous phenomena of the discharge processes were examined by an image converter camera and a still camera.

Furthermore, before and after the frequent discharges, the surface condition of the protrusion exposed to the impulse discharges was observed by an electron probe microanalyser, and the binding energy of $\mathrm{Cu}-2 \mathrm{p} 3 / 2$ at the protrusion surface was investigated by means of a $\mathrm{x}$-ray photoelectron spectroscope.

The main results are as follows: (1) The time till arc occurrence in the configuration with protrusion as compared with one in the configuration without protrusion is larger for low applied voltages and smaller for high applied voltages. (2) As the number of times of the discharge is increased, the time till arc occurrence is later and finally both of the time and the length of the discharge channel become roughly constant. (3) The surfaces of protrusion and plane are oxidized by frequent impulse discharges. Consequently, the change of cathode spot position occurs.

\section{キーワード：インパルス放電，アーク放電，グロー放電，表面分析，酸化，二次電子像，特性 X 線像}

\section{1.まえがき}

気体の放電電圧は，陰極材料の違いや放電空間の不 純物の影響を受け，更に污損や酸化などによる陰極表 面状態の効果で，一般に，不安定になることがわかっ

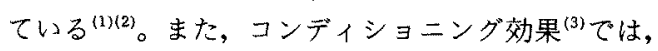
小勢力の放電を絽返すことにより火花電圧が上昇し, やがて一定值に落着くことが知られている。
このような放電電圧の不安定性や上昇の原因を明ら かにするために，除極表面状態の効果に着目した研究 が行われている。その例として, 放電電圧の変化を, 陰極表面の仕事関数と結び付けたものの出)(5)や，電極表 面の吸着物との関係で調べたものがある到(2)。ほかに も，インパルス破壊に伴って生じる陰極表面の酸化膜 と破壞のフラッシオーバ率との関係が調べられてい る(6)。これらの, 放電特性に影響するパラメー夕の解 
明とそれらの放電特性に対する効果についての研究 は, 機器の機能や絶緑を確保するうえで重要であるに もかかわらず，十分に行われているとはいえない。

そこで著者らは, 低気圧空気中で針対突起付き平 板に雷インパルス電圧を繰返し印加して, 繰返し放電 による陰極表面とギャップの放電特性の各変化を調べ た。電極が針対突起付き平板の場合, アーク放電路 は, 針対突起間で始まり, 放電回数の增加と共に針対 平板間に移動した。そこで,この放電特性の変化を, ギャップの長さが等しい正針対平板のものと比べた。 突起電極は, 繰返し放電によって変化した陰極表面の 観測・分析用の試料として利用することができた。

その結果, 比較的低い印加電圧領域での正針対突起 付き平板電極系のアーク開始までの時間は，突起があ っても, 正針対平板電極系のものより長くなり,アー ク出現のための印加電圧は高くなることがわかった。 これに対し, 比較的高い印加電圧領域では, 高い電界 を形成し得る突起が平板にあるので, 初期のアーク開 始までの時間は正針対平板電極系のものより短かっ た。しかし，放電を繰返した後のアーク開始までの時 間は, 突起の特性が現れにくくなって, 次第に長くな ることがわかった。アーク開始時間が放電回数の増加 と共に長くなるのは, 陰極の表面状態が放電を繰返す ことによって変化（酸化）するからである。このこと は, 電子線マイクロアナライザと $\mathrm{X}$ 線光電子分光装 置による観測から明らかとなった。

なお，著者らは，アーク開始時間が放電回数の增加 と共に長くなり, 放電電圧が高くなる現象は針対平板 についても明らかにし，一部を報告している゙ク。

以下，これらについて報告する。

\section{2. 実験の装置と方法}

電極系の正針としては, 先端を半球状に仕上げた $\phi 1 \mathrm{~mm}$, 長さ $30 \mathrm{~mm}$ のタングステン棒を, 棒状補助 電極の先に取付けて用いた。陰極としては, 周囲を 丸めた $\phi 150 \mathrm{~mm}$ の銅平板, $\phi 100 \mathrm{~mm}$ 黄銅平板を 用いた。正針対突起付き平板の場合, この平板の中央 に, 先端を半球状に仕上げた $\phi 2 \mathrm{~mm}$ の銅または黄銅 製突起を設け, 突起の高さ $(h)$ は $10 \mathrm{~mm}$ まは 5 $\mathrm{mm}$ とした。正針と平板, 正針と突起先端間のギャッ プの長さ $(d)$ は等しくし， $d=60 \mathrm{~mm}$ または $80 \mathrm{~mm}$ とした。

乫起電極は，まずエメりー紙，金属研磨郕（ピカー ル）で研磨し，アルミナ $\left(\mathrm{Al}_{2} \mathrm{O}_{3}\right.$, 粒子径 $\left.0.3 \mu\right)$ でそ の表面を鏡面状に仕上げた後，アセトンを浸した清浄 な布で拭いた。この突起電極は，更にトリクロール

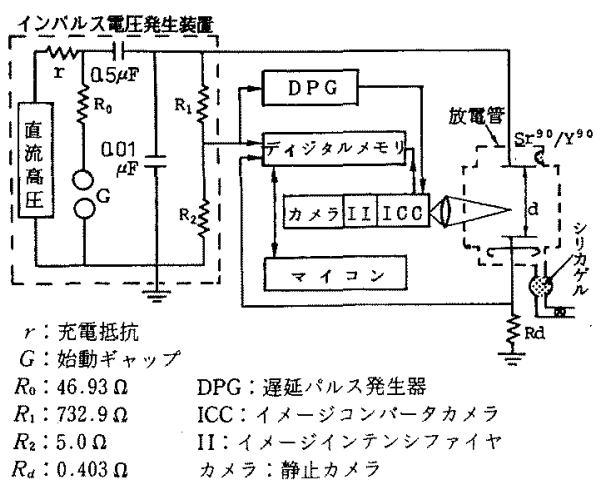

図 1 実験回路と装置

Fig. 1. Experimental circuit and apparatus.

エチレンと蒸留水で, または蒸留水のみでそれぞれ 10 分間の超音波洗浄を行い, 約 $10^{-2}$ Torr の空気中に 1 時間放置して乾燥した後, 実験に供した。平板電極 も必要に応じて上記の研磨・洗净処理を行った。

供試気体は, シリカゲルを通して乾燥した室内空気 で，電極系を設置したパイレックスガラスシリンダ内 に充てんし, その圧力 $\left(P_{r}\right)$ は 8 Torr 一定とした。

図 1 に実験回路と装置を示す。印加電圧 $\left(V_{a}\right)$ は放 電しないときに針端に現れる電圧で， $1 / 300 \mu \mathrm{S}$ の正極 性雷インパルスである。印加電圧の波尾をこのように 長くすることによって，グロー，アークの出現と放電 特性の解析を容易にすることができた。放電時の電圧 $(V)$, 電流 $(I)$ は, ディジタルメモリーで観測し、マ イクロコンピュータに記憶してデータの解析などに用 いた。ここで, 電圧印加後アークが開始するまでの時 間 (アーク開始時間, $\left.T_{a}\right)$ と放電回数 $(N)$ との関係 を調べた。

また $V, I$ の観測と同時に, 放電の発光過程をイ メージインテンシファイヤ（II）付きのイメージコン バータカメラ (ICC) で観测した。更に, 放電回数に 対するアーク放電路の変化を静止写真で観測した。

突起電極の表面は, 放電の前後に電子線マイクロア ナライザ (EPMA) で観測し，まず二次電子像 (SEI) の観測から電極表面の放電こん跡の分布を明 らかにした。次に, 特性 X線スペクトルの観測から 放電こんとその周囲に含まれる元素を調べ, 各元素 の特性 X 線像からその元素の分布を明らかにした。 更に，銅製突起電極の表面を，放電の前後にX 線光 電子分光装置 (XPS) で観測し ${ }^{(8)}$, 放電によってでき た表面物質を調べた。

アーク開始時間特性の実験は主に陰極として銅製突 
起付き平板を用い, $d=60 \mathrm{~mm}, h=10 \mathrm{~mm}$ として行 つた。黄銅製突起付き平板は主に陰極の酸化特性をよ り明らかにするために用い, その場合, $d=80 \mathrm{~mm}$, $h=5 \mathrm{~mm}$ とした。

\section{3. 実験結果}

〈3・1〉 アーク開始時間特性 図 2 に, 正針対突 起付き平板電極系と正針対平板電極系の, アーク開始 時間特性を示す。突起と平板の材質は銅で $h=10 \mathrm{~mm}$ の場合である。同図で，正針対突起付き平板電極系の アーク開始時間 $\left(T_{a}\right)$ (その分布と平均を一○一で図示) は，針対平板のもの (- $\Delta$-で図示) に比べ, $V_{a}$ が高 い領域（以下, 高 $V_{a}$ ) では短く, $V_{a}$ が低い領域（以 下, 低 $\left.V_{a}\right)$ では逆に長い。ここで, 両電極系の $V_{a}-$

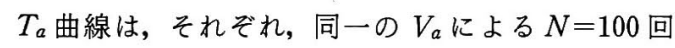
の絽返し放電を各 $V_{a}$ について行い, この実験を 5 回 繰返して得た, 各 $V_{a}$ の $N=1 \sim 10$ 回における平均 $T_{a}$ 值から求めた。従って, 図中の $O, \triangle$ 印による值 は, 50 個のデータから求めた $T_{a}$ の平均值である。 100 回の繰返し放電による $T_{a}$ 值は, いずれの場合も, $N$ の増加に対して上昇, 飽和の傾向を示した。 $N=1$ $\sim 10$ 回の $T_{a}$ 値はこの上昇過程の初期の值である。従 って, これらの平均で示した図 $2 の V_{a}-T_{a}$ 曲線は, 初期上昇過程に招ける, $N$ の増加に対する $T_{a}$ の平均 的特性を示している。 $N=1 \sim 10$ 回の放電について は, $T_{a}$ のほか以下に述べる特性を調べ, それらを $N$ を更に増加させた場合のものと比較・検討した。な お, 第 2 章で述べたように, 各 100 回の繰返し放電を 行う前に電極処理を行っている。

図中の $(a)$ 点と $(b)$ 点における放電過程の流し写 真, こま写真と電圧, 電流波形のオシログラムを図 3 に示す。図 2 の低 $V_{a}$ による $(a)$ 点では, 放電路の 放電相は, まず, 陽光柱が拡散した拡散グロー $(\mathrm{DGP})^{(9)}$ から, 次に, 図 3(a)のこま写真(1) に示す

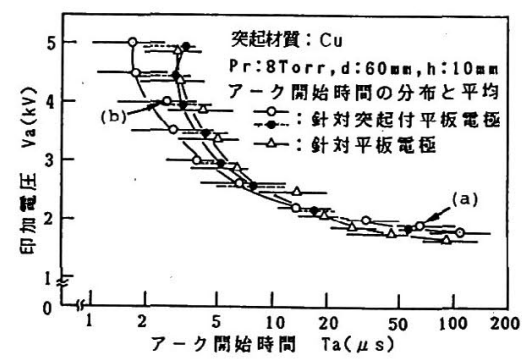

図 2 アーク開始時間の電圧特性

Fig. 2. Characteristics of arc ouucrrence time to applied voltage.
ように陽光柱が収縮部 (CPC) と拡散部(DPC)からな る移行グロー ${ }^{(9)}$ に変わる。その後, 移行グロー中のファ ラデー暗部(FDS)が消失しかつ, DPCが CPCに変わ って, 図 3(a)のこま写真 ( 3 ) に示すように, 移行グロ 一から収縮グロー(主に収縮した陽光柱と負グローか らなるグロー放電) $)^{(9)}$ に移行する。この段階では, ギ ヤップはほほ収縮した陽光柱で橋絡されるが, 突起部 分と平板上には拡散した負グロー(NG)が残る。放電 回数を増加させると, 陰極近傍のこの拡散した放電に よって突起先端の電界が䋸和されかつ電極表面が変化 (酸化)され得るので, 突起先端部には, 放電路をアー クにする陰極点は形成されにくくなる。従って, アー クへの移行は CPC が突起先端から更に平板まで伸び て，そこに陰極点を形成した段階で行われる。すなわ ち, 低 $V_{a}$ では放電路が伸びて実質上, 気圧とギャッ

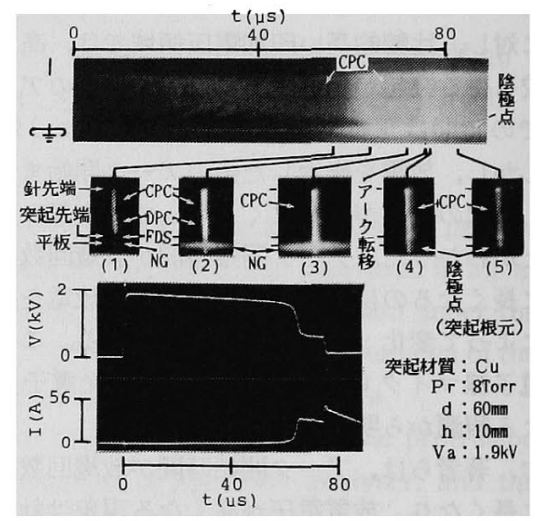

（a）陰極点が突起根元に形成される場合

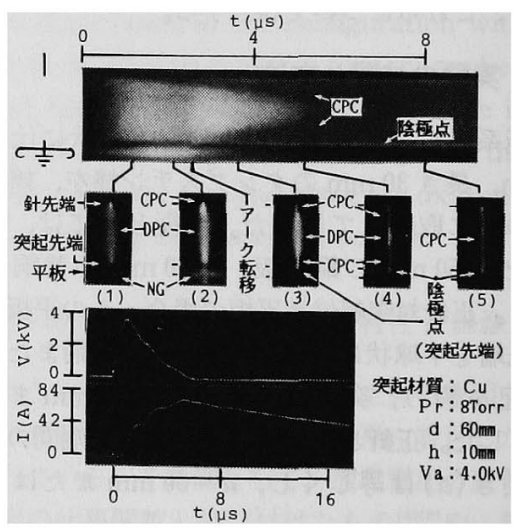

（b）陰極点が突起先端に形成される場合

図 3 フラッシオーバ過程の流し撮り,こま 撮り写真と $V, I$ 波形

Fig. 3. Streak, framing photographs and $V, I$ wave forms of flashover process. 


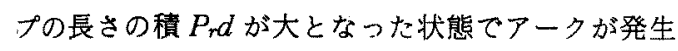
するのて，正針対突起付き平板電極系の $T_{a}$ は，図 2 のように正針対平板電極系のものより長くなる。この 場合の $T_{a}$ 值は $d=70 \mathrm{~mm}, h=0 \mathrm{~mm}$ の正針対平板 のものとほほ等しいことを別に確認した。

これに対し，(b) 点では，高 $V_{a}$ にっって平板側の $\mathrm{NG}$ の領域が小さくなり, 突起先端の電界が高くな る。そこで，図3(b)に見られるように，CPCが正 針側から平板側へ進む過程で平板上の突起先端にも別 のCPCが現れ，ギャップ中間に向かって進む。この ギャップ中間へ進む CPCによって，正針と突起間の 放電路の収縮が促進され，放電路と除極の加熱も進む ことが考えられる。更に高 $V_{a}$ によって突起先端の電 界が高くなるので, $N$ が約 20 回以下では陰極点は突 起先端にできることが多く、アークへの移行も早くな る。高 $V_{a}$ では，このような理由で，正針対突起付き 平板電極系の $T_{a}$ は正針対平板電極系のものより短く なることがわかった。

図 2 の印による值は，正針対突起付き平板電極系 の, 突起を研磨・洗浄した後に同一 $V_{a}$ で繰返し放電 を 90 回行ってから求めた, 91〜100 回目の $T_{a}$ の 5 回 分の実験值の平均である。この値は○印のものより長 くなっておうり，多数回の放電で乫起の陰極機能が抑制 されて Taが長くなることがわかった。この場合, 陰 極としての突起は銅製であり，その表面は放電回数が 堌加すると茶褐色に変化する。突起が多数の放電こん 跡を含むこの姿色領域でおおわれると，陰極点は突起 に形成されず乫起の根元あるいは平板上に形成される ようになる。すなわち，P P r が実質上大となった効 果が現れるようになるので,このように $T_{a}$ は長くな るものと考えられる。な㤃, 陰極表面の変化について は，〈3・4〉節の EPMA による観測と〈4・2〉節のXPS による分析で詳しく述べる。

\section{〈3・2〉放電回数とアーク開始時間 図 4 は同一} $V_{a}$ による,インパルス放電の放電回数に対するアー ク開始時間特性 $\left(N-T_{a}\right.$ 特性)を示したものである。 同図からわかるように, Taは, $N$ が 10 回程度まで はほほ $1 \sim 4 \mu \mathrm{s}$ と短く, $N$ の增加と共に長くなり, 20 回以後では $6 \mu \mathrm{s}$ 程度となって安定した。

これに対応して, 陰極点は初め笑起先端部に形成さ $れ, N$ の增加と共に突起側面へ移動し, $T_{a}$ が $N$ の 增加でほぼ飽和して一定値に落着いた段階では, 突 起の根元付近に形成された。更に，本実験で行った以 上に $N$ を增加させると，あるいは $V_{a}$ を低くすると， 陰極点は突起の根元を離れて平板上に形成されること を, 別に確かめた。いずれの場合も、アーク放電路は

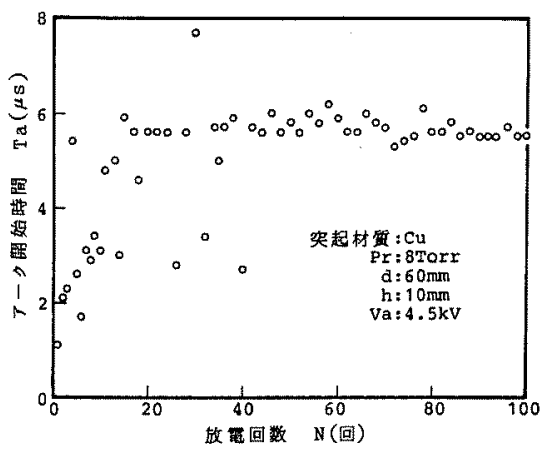

図 4 放電回数に対寸るアーク開始時間の変化

Fig. 4. Change of arc occurrence times with discharge numbers.

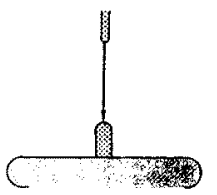

(a) タイプ A

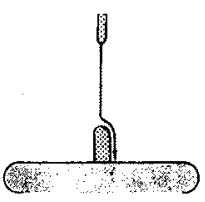

(c) タイナ゚C

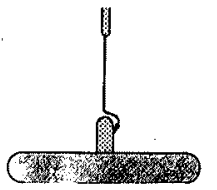

(b) タイプ B

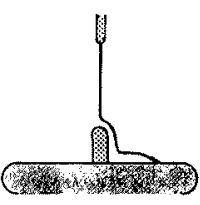

(d) タイプD
図 5 放電路タイプのモデル

Fig. 5. Model of discharge channel types.

正針と陰極点問に現れ，この放電路つまり見掛けのギ ヤップの長さは $N$ の增加と共に長くなった。これら のことは，〈3・1〉節で述べた $N$ の増加でアーク放電路 が長くなり， Taが長くなり得ることを更に実証して いる。

従って, $N$ の増加による放電路のタイプは, 図 5 に示すように,ほほ $A, B, C, D$ 種にモデル 化することができる。放電路のタイブは，図40説明 で述べたように，Nの增加と共に $A \rightarrow B \rightarrow C \rightarrow D$ と 変化するが，Dタイプは安定して出現しない。なお， 低過電圧印加での放電路タイプは, Dタイプが出現 するようになった後，アークが出現せずにグローで終 る放電路タイプに変化することを別に確かめた。

印加電圧を変えた場合の, $N-T_{a}$ 特性と放電路夕イ プを図 6 に示す。図中の表は, 各 $V_{a}$ で出現する放電

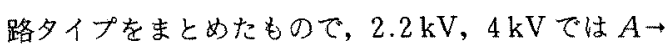
$B \rightarrow C, 2.7 \mathrm{kV}$ では $A \rightarrow B \rightarrow C \rightarrow D$ となることを示 


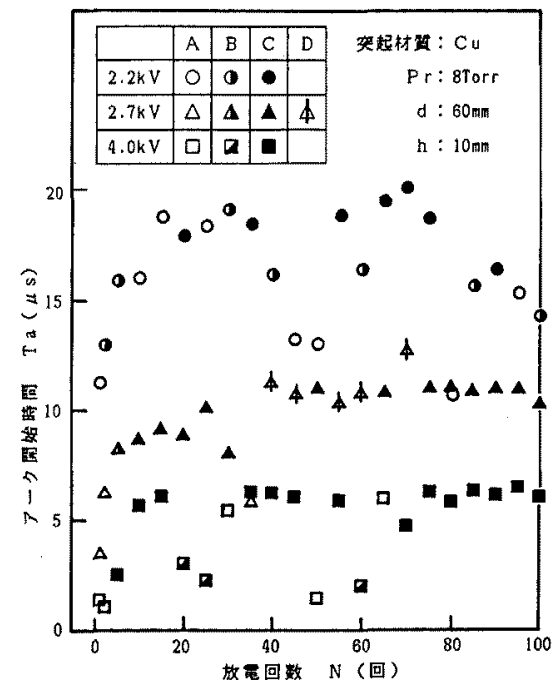

図 6 アーク開始時間と放電路タイプ

Fig. 6. The relation of arc occurrence times and discharge types.

している。N-T $T_{a}$ 特性は， $T_{a}$ が低 $V_{a}$ で長く高 $V_{a}$ て 短く，高 $V_{a}$ になるほどアークの形成が容易となって $T_{a}$ が短くなることを示している。また同図では， $V_{a}$ を変えても, 放電は $A$ タイプで始まって $T_{a}$ は短く, その後 $N$ の増加によって， $T_{a}$ は長くなり放電路タイ プも変わっている。このことは, 放電は初め高電界を 形成する突起と針電極間で起こるが，放電を繰返す と, 突起の表面が変化しその効果, すなわち表面酸化 による放電の抑制によって $T_{a}$ が長くなり，陰極点も 移動して放電路夕イプが変化することを示している。

なお， $N=100$ 回の本実験範囲では， $T_{a}$ は $N$ の增 加によってほほ飽和し，放電路タイプもほほ一定とな るが，これは主に電極の形状と配置によって放電の広 がりが限定されることによる。Bタイプの放電路は $T_{a}$ が飽和する以前にはわずかに出現するだけである が,これは，陰極点の形成筒所が突起側面であり，そ こでは陰極点の形成が困難となるからである。また， Taが活㴗飽和した段階で, 初めと同じく $A$ タイプや $B$ タイプが出現して放電路夕イプが不安定になるの は, 縲返し放電によって突起のみならず平板表面まで が变化して突起先端の高電界効果が再び現れやすくな るからであろう。

ここで問題になるのは，放電の繰返しによって放電 しにくくなりアーク長が伸びることであり，原因とし て電極表面の放電による変化（酸化）とその効果が考 えられる。このことについては, EPMAとXPSを

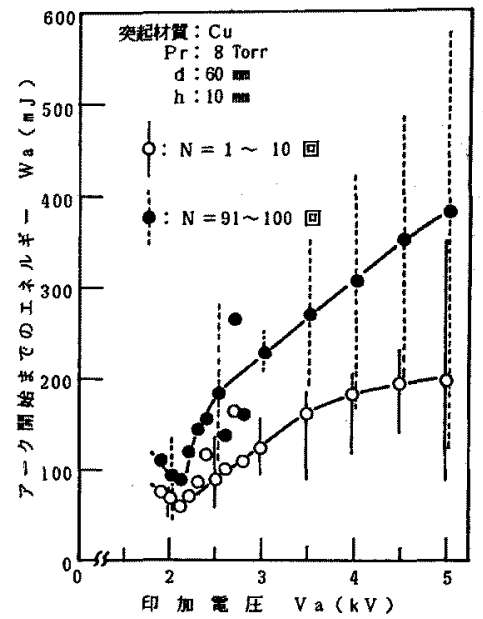

図 7 アーク開始までのエネルギーの電圧特性 Fig. 7. Characteristics of energy till arc occurrence to applied voltages.

用いた表面の観測・分析によって述べる。

〈3・3〉 アーク開始までの注入エネルギー 図7 は，図 2 の正針対突起付き平板電極系について求めた アーク開始までの注入エネルギー $\left(W_{a}\right) を, N=1 \sim$ 10 回と $N=91 \sim 100$ 回に招ける平均值の分布とその 各平均について示したものである。同図で $W_{\mathrm{a}}$ は, $N$ $=91 \sim 100$ 回では $N=1 \sim 10$ 回の約 2 倍程度になって いる。 $W_{a}$ が $N$ の増加と共に増加する理由としては, 放電を繰返したことによる電極表面の変化の効果が考 えら机る。すなわち，絽返し放電によって電極表面が 酸化された結果, 放電が抑制され, 放電領域が広が り，陰極点の形成が困難となってグロー継続時間が長 くなるので，工ネルギーの積分值としての $W_{a}$ が増加 することが考えられる。また， $V_{a}$ 上昇による $W_{a}$ の 增加から， $V_{a}$ が高くなるほど電極表面の酸化が進む ことが考兄られる。

同図で最小の $W_{a}$ を示す $V_{a}$ は，図 2 の○印と $\Delta$ 印 で示した二つの曲線の交差点の $V_{a}$ にほほ一致する。 $V_{a}-W_{a}$ 特性は, この $V_{a}$ を境として二つの種類に分 けられる。一つは図3(a)に示したタイプの放電によ るもので， $V_{a}$ の低下で $T_{a}$ が長くなり $W_{a}$ が上昇す る。もう一つは図 3(b)に示したタイプの放電による もので, $V_{a}$ の上昇で $T_{a}$ が短くなるが $W_{a}$ が上軎す る。前者では, 低 $V_{a}$ であるほど, アーク開始前のグ ロー期間が長くなって酸化よりも低 $V_{a}$ の効果が現 れ, 後者では高 $V_{a}$ ほど酸化が進んで著しい酸化効果 が現れこのように $W_{a}$ が増加することが考えられる。 

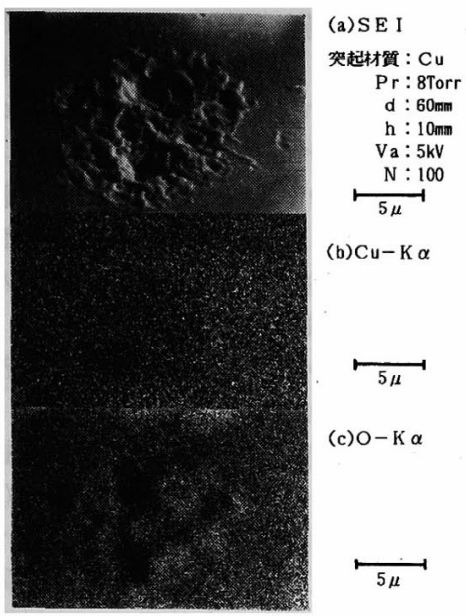

(b) $\mathrm{Cu}-\mathrm{K} \alpha$

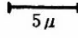

(c) $\mathrm{O}-\mathrm{K} \alpha$

図 8 銅の $\mathrm{SEI}$ と $\mathrm{Cu}, \mathrm{O}$ の特性 $\mathrm{X}$ 線像

Fig. 8. SEI of copper and characteristic $\mathrm{X}$-ray images of $\mathrm{Cu}, \mathrm{O}$.

\section{〈3・4〉 EPMA による陰極表面の観測 SEI から} は変色(酸化)領域と放電こんの形状がわかり, 特性 $\mathrm{X}$ 線像からはその $\mathrm{X}$ 線を放射する元素の分布がわか る。そこで，まず銅製突起付き平板の突起の表面を $\mathrm{SEI}$ と $\mathrm{Cu}-\mathrm{K} \alpha, \mathrm{O}-\mathrm{K} \alpha$ の特性 $\mathrm{X}$ 線像で調べた。それ ぞれの視野は茶蝎色に変色した部分の同一筒所とし た。図 8 は高 $V_{a}$ による放電を 100 回繰返した後に求 めた。

（a 図のSEIから，加熱，イオン衝撃などによるも のと思われる溶融, 衝撃, 飛散, たい積の後が認めら れる。これらのこん跡は, 未放電の突起では観測され ず，放電によって変色したところほど多く観測される ことから，繰返し放電による放電こんである。(b)図 はCu- $\mathrm{K} \alpha$ の特性 $\mathrm{X}$ 線像である。突起が銅製であるの で, この図から突起上の放電による $\mathrm{Cu}$ 分布の変化を 詳しく知ることはできない。しかし，同図上の X 線 像は放電こんでやや暗いことから，Cuは放電こん表 面ではやや低濃度となることが認められる。これに対 し， O-K $\alpha$ の特性 X 線像は，(c) 図に示したように, 放電こんの突出部で明るく, 衝撃による凹部で暗くそ して残りの視野領域ではほほ一様に分布した。像の明 暗は表面形状などにも影響される(10)ので，それがそ のまま元素の分布には結びつかない。しかし, 放電こ ん表面では $\mathrm{Cu}$ 濃度がやや低下するので，酸素は放電 によって突起表面に広く分布し放電こん突出部にはか なり含まれるようになることが認められる。

一方, 陰極点が形成される前後の突起付近の気体温

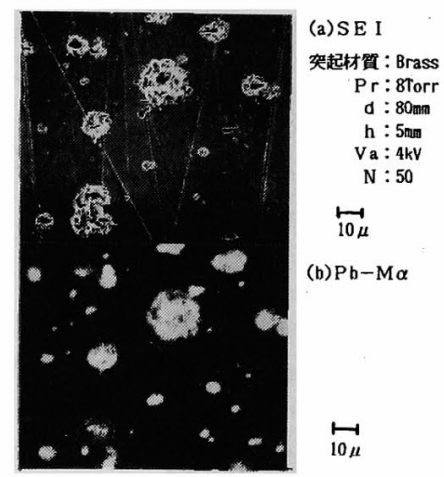

図 9 黄銅の $\mathrm{SEI}$ と $\mathrm{Pb}$ の特性 $\mathrm{X}$ 線像

Fig. 9. SEI of brass and characteristic $\mathrm{X}$-ray image of $\mathrm{Pb}$.

度は $\mathrm{Cu}$ の融点 $\left(1,083^{\circ} \mathrm{C}\right)$ 以上となる ${ }^{(11)} の て ゙$, 陰極点 形成前後の陰極表面は，成分である銅の溶融や著しい 酸化が起こり得る状態にある。また, 突起付き平板 は, アーク発生前のグローの期間，図 3 に示したよう に負グローで扔扔われていて，そこでは放電が行われ ている。

これらの観測結果から，銅製の突起付き平板表面は グローとアークからなるインパルス放電によって酸化 され，特に放電こんの突出部は強く酸化されることが わかった。従って, 放電を繰返すことによって酸化度 が増し，酸化領域が広がり，その結果，放電によって 陰極表面があれるにもかかわらず陰極点が移動して， 放電特性が変わるようになることが考えられる。な お，この場合，酸素は吸着酸素や酸化銅の形で分布す るものと考えられる。そこで，放電による酸化銅の生 成をXPS で調べた。その結果は〈4・2〉節で述べる。

本実験では，陰極における放電こん生成と酸化の特 性をより明らかにするために，黄銅製突起付き平板の 突起表面もEPMA で観測した。その結果を次に述 べる。

この場合, 黄銅中には, $\mathrm{Cu}$ と $\mathrm{n}$ は $6: 4$ の割合 で, $\mathrm{Pb}$ は $1.8 \sim 3.7 \%$ の含有率で含まれる。 $\mathrm{Pb}$ の融 点は, 主成分の $\mathrm{Cu} \mathrm{Zn} の も の に$ 比べて低く, $327^{\circ} \mathrm{C}^{(12)}$ である。SEI と特性 X 線像は, 放電こんが多 くて白く変色したところを視野とし， $V_{a}=4 \mathrm{kV}, N=$ 50 回で求めた。 $d=80 \mathrm{~mm}, h=5 \mathrm{~mm}$ としたが,こ の場合も，正針対黄銅製突起付き平板の $V_{a}-T_{a}$ 曲線 は図 2 の場合と同じく，正針対黄銅製平板の $V_{a}-T_{a}$ 曲線と交差し，その高 $V_{a}$ 領域では $N$ の増加によっ て $T_{a}$ は長くなる ${ }^{(8)}$ 。また，ギャップ間に形成される 放電は， $4 \mathrm{kV}$ と高 $V_{a}$ であるので，短いグロー期間 


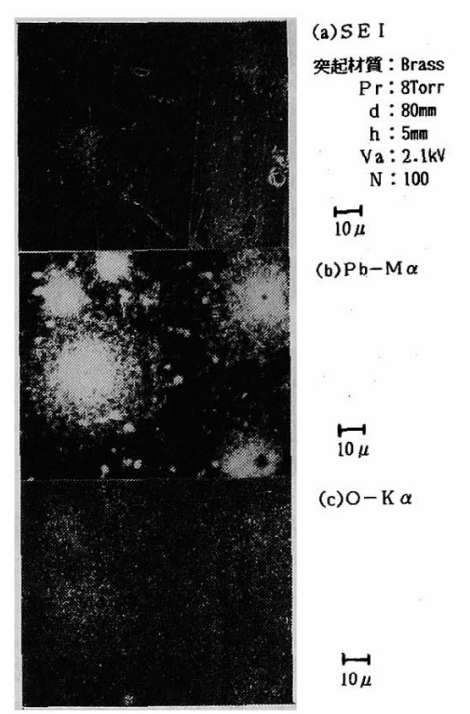

図 10 グロー放電後の黄銅の SEI と $\mathrm{Pb}$, $\mathrm{O}$ の特性 X 線像

Fig. 10. SEI of brass and characteristic $\mathrm{X}$-ray images of $\mathrm{Pb}, \mathrm{O}$ after glow discharges.

を経てアークへ移行するインパルス放電である。

このときの SEI と $\mathrm{Pb}-\mathrm{M} \alpha$ の特性 $\mathrm{X}$ 線像を図 9 に 示す。この場合の放電こんの規模は， $V_{a}=4 \mathrm{kV}$ によ る図 $9(\mathrm{a})$ と $V_{a}=5 \mathrm{kV}$ にるる図 $8(\mathrm{a})$ におる放電 こんの比較からわかるように，銅製突起のものより大 きくなり得る。これは黄銅製突起の場合，柔らかくて 融点の低い $\mathrm{Pb}$ が含まれており，これが早めに融出さ れて長い期間放電の影響を受けやすい状態にあるから であろう。この $\mathrm{Pb}$ は, 図 9(a),（b)の対比からわ かるように，そのほとんどが放電こん表面に現れる。 これに対し，特性 X 線像の観測から，突起の主成分 であり，融点が高い $\mathrm{Cu}$ (融点 $: 1,083^{\circ} \mathrm{C}$ ) と $\mathrm{Zn}$ (融 点： $419^{\circ} \mathrm{C}$ ) は銅製突起の場合と同じく視野領域には 広く分布するが，放電こんではやや低濃度になること が認められた。酸素も，銅製突起の場合と同じく，視 野領域ではほほ一様に分布するが，放電こんではかな り含まれるようになることが観測された。

この観測から，陰極が黄銅製の場合も，グローとア ークからなるインパルス放電によって陰極表面は広く 酸化されることがわかった。また，陰極に低融点の $\mathrm{Pb}$ が含まれるので，放電こんは銅製の場合より大き くなり，放電こんは主に酸化鉛によっておおわれるこ とや残りの表面は酸化銅，酸化亜鉛などでおおわれる ことが考えられる。この場合, 酸化銅と酸化垔鉛の分 布にも，主に融点の違いから，相違が考えられる。
図 10 は, 図 9 の場合と同じギャップ条件で, $V_{a}=$ $2.1 \mathrm{kV}$ と $V_{a}$ を低くしてアークの発生を防ぎ, 放電 相の進展をグローまでとしたインパルス放電のもので ある。放電過程に現れるグローは拡散グロー (DGP) $)^{(9)}$ で電流の波高值は約 $1 \mathrm{~A}$ と小さいが, その継続時間 は数百 $\mu \mathrm{s}$ とかなり長い。 SEI と特性 X線像は, $N$ $=100$ 回と放電回数を増やした後に, 放電こんが顕著 に現れるところを視野として求めた。

図 10(a)のSEI から，インパルスグロー放電によ る放電こんは比較的大きく，しかしそれは $1 \sim 2 \mu \mathrm{m}$ 以下の小規模な形状変化の集団がほほ円形に拡散・分 布したものであることがわかった。 $\mathrm{Pb}$ は，(b)図の $\mathrm{Pb}-\mathrm{M} \alpha$ の特性 $\mathrm{X}$ 線像からわかるように, 図 9 に示し たインパルスグローアーク放電による場合と同様各形 状変化とその集団からなる各放電こんに対応して融 出・分布した。従って, 陰極が融点の高い銅の場合, インパルスグロー放電によって形状変化が生じても, 各形状変化は小さくなることが考えられる。また，ク゚ ローにアークが続くインパルス放電による場合，この ような小規模集団からなる放電こんは確認できなかっ た。従って,グローに続くアークは，グローによる小 規模集団からなる放電こんの上に図 9 に見られるよう な規模の大きい放電こんを作ることが考えられる。し かし，放電を繰返すことによって酸化が進むので，放 電を繰返した場合の放電こんは移動するようになり， 放電路と $T_{a}$ が次第に長くなることが考えられる。

酸素については図 $10(\mathrm{c})$ のような特性 X 線像が得 られた。その分布は, 視野の全面に広がるが, (a), (b)図のものと一致してほほ放電こん上に濃く現れ た。一方, $\mathrm{Cu}$ と $\mathrm{n}$ の分布はこの場合も視野全面に 広がるのみであった。これらのことから, インパルス グローによっても酸化が行われ, 酸素は, 吸着酸素, 酸化銅, 酸化亜鉛の形で陰極表面に分布し得, 酸化鉛 として放電こん表面に著しく分布し得ることが考えら れる。 $T_{a}$ やアーク長が長くなり, $W_{a}$ が増加する原 因として，このような酸化物の形成と広がりが挙げら れるであろう。

\section{4. 検討・考察}

\section{〈4・1〉 アーク開始時間とコンティショニング}

$\langle 3 \cdot 2\rangle$ 節で述べたように, $T_{a}$ 值は放電回数の増加と 共に大きくなり，一定値に落着く傾向がある。その理 由として, まず陰極点の移動で放電路が長くなって実 質の過電圧率が低下するので $T_{a}$ 值が大となる, ある いはアーク開始電圧が上昇することが考えられる。こ の場合， $T_{a}$ が一定値に落着く傾向は，実質のP $P_{r} d$ が 


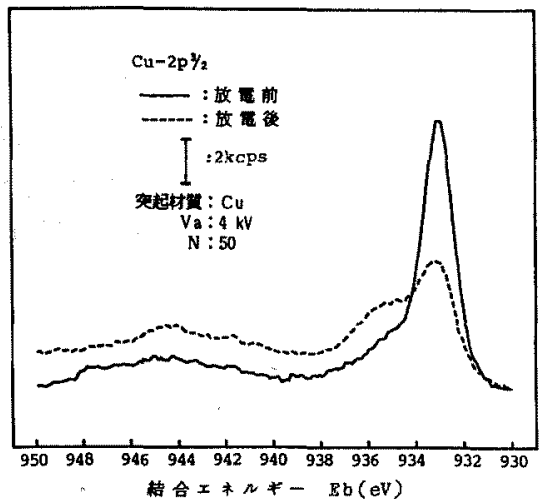

図 11 放電による銅の光電子スペクトル の変化

Fig. 11. Change of photoelectron spectra of copper by exposing impulse discharges.

電極の形状や配置などに制約されてあまり長くなり得 ないからであるう。従って, 繰返し行われる放電はあ たかもコンディショニング(3)としての予備放電の役目 を果たすことになる。

一方, 放電回数が増加すると放電こん数が増えて陰 極の突起と平板の各表面蛙荒机る。それにもかかわら ず陰極点が突起の先端付近から移動する理由として は，SEI や特性 X 線像による観測から，放電こんが 形成された部分ほど，そして放電回数が増加するほど 酸化が進むことを挙げた。実際に，放電こんが形成さ れ，変色した乫起付き陰極では $T_{a}$ 值が大となること も示した。これらについては，放電こんを形成してい る物質に誘電体特性があるかどうかを別途調べる必要 がある。しかし，酸化によって放電電压が上がること は知られている(6)ので，本研究ではまずEPMAによ る観測から酸化物の生成があり得ることを確認した。

なお，本実験では，陽極の効果にはふれていない。 この場合，陽極は，タングステン製でその融点は高く $\left(3,382^{\circ} \mathrm{C}\right)$, 外観的に損傷は少なく, 別の実験で放電 特性に与える影響はほとんどないことを確かめたの で，本論文では陰極の効果のみで述べている。

〈4・2〉XPS による表面酸化の確認 図 11 は, 銅製突起の表面をXPSで観測したものである。同図 の実線で示した未放電試料のスペクトル分布で，純銅 の $2 \mathrm{p} 3 / 2$ のスペクトルは結合エネルギー $\left(E_{b}\right)$ が 933 $\mathrm{eV}$ でピークを示す。破線で示した放電後のスペクト ル分布ではこのピーク值が相対的に低下し，わずかな がらピークシフトが生じているほか, 約 $935 \mathrm{eV} に$ $\mathrm{CuO}^{(13)}$ に相当する新たなスペクトルピークが形成さ
れている。これは， $N=50$ 回の放電で突起表面が著 しく酸化されたので, 純銅スペクトルの低下と酸化物 によるケミカルシフトが観測されたことを示す。この 酸化物については, $945 \mathrm{eV}$ 付近にもスペクトルピー

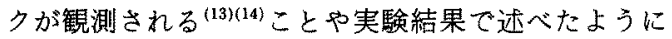
放電抑制の働きをすることから，主に $\mathrm{CuO}^{(15)}$ と考元

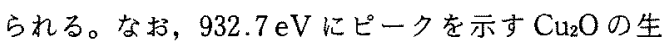
成による影響も考えられる。このほか，Pb-4f7/2， $5 / 2$ の光電子スペクトルが高エネルギー側へ, O-1s の光電子スペクトルが低エネルギー側ヘシフトするこ とから, $\mathrm{Pb}$ の酸化物の生成が確認された ${ }^{(16)(17)}$ 。

突起付き平板の場合の陰極点注, 放電回数が少ない 間はまず電界の高い突起先端部に多く形成されるが, 放電回数が増えるとこのように酸化物が生成され，そ れは絶縁物 ${ }^{(15)}$ として突起先端付近の放電を抑制し得 るので，突起先端部から離れたところに形成されるよ うになる。すなわち, 放電路が変化し実質のP $P_{\text {d }}$ が 大となってこの効果が現れ、アーク開始時間の増加な どがもたらされることになる。

\section{5.むすび}

低気圧空気中の雷インパルス放電で，正針対突起付 き平板電極のアーク開始時間特性を調べ, 正針対平板 電極のものと比較した。更に突起電極の表面状態を電 子線マイクロアナライザと $\mathrm{X}$ 線光電子分光装置で観 測し, 表面状態とアーク開始時間などとの関係を調 べた。

\section{主な結果は次のとおりである。}

(1) 正針対突起付き平板電極系のアーク開始時間 は，正針対平板系のものに比べ印加電圧が低い領域で は長く, 印加電圧が高い領域では短い。

（2）印加電圧が高い領域でのアーク開始時間は放 電回数と共に長くなり,一定値に落着く傾向があ る。

（3）印加電圧が高い場合，アーク開始時間は短 く, 陰極点㹥突起先端付近侄形成されるが, 放電回数 の増加と共にアーク開始時間は長くなり, 陰極点は突 起根元付近に移動し, 更に平板上に移動してアーク放 電路が長くなる。

（4）突起表面にできる放電こんは，放電回数と共 に増加し，アークを含む放電では形状変化の著しい 個々の放電こんの集中した形のものとなり，グローま でしか進展しない放電では形状変化の小規模な放電こ んの集合した円形拡散形のものとなる。

（5）放電を繰返すことによって，陰極表面には絶 縁物としての酸化物が形成され，それが突起先端部の 
著となり，陰極点は突起先端部を避けて形成されるよ うになるので，実質の放電路が長くなりアーク開始時 間が長くなる。

最後に, 電子線マイクロアナライザと X 線光電子 分光装置による観測に便宜を図っていただいた宮崎県 工業試験場富山幸子技師, 武蔵工業大学 光井英雄教 授, 磯野一助手[現在, 日本精密工業(株)]に感謝の意 を表します。また，実験に御協力いただいた卒業研究 生諸君に感謝いたします。

(平成 2 年 6 月 24 日受付, 同 2 年 8 月 28 日再受付)

\section{文献}

（1）磯野・杉野・曾雬・光井：「陰極表面付着物の気中直流破壊 に及ほす影響」, 電学論 A, 103, 625（昭 58-11）

（2）磯野・杉野・曾粨・光井：「陰極（アルミニウム, 鉄, 金) 表 面付着物の気中直流破壊に及ほす影響」, 同上 A, 105, 9 (昭 60-1)

（3）電気学会：放電ハンドブック改訂新版, p. 215（昭 59）オーム 社

（4）中村・森：「タウンゼント放電域の火花電圧に及ほすす陰極表 面状態の影響 (1)」, 電学論 A, 92, 357 (昭 47-7)

（5）佐伯・中村・森：「タウンゼント放電域の火花電圧に及ほすす 除極表面状態の影響 ( 2 ) 」, 同上 A, 94, 411（昭 49-10)

（6）杉野・曾襧・鳥山・光井：「大気中インパルス破壊に伴う電 極表面の履歴及び履歴の放電特性に与える影響」, 同上 $\mathrm{A}$, 100, 617 (昭 55-11)

（7）大坪・竹内・池尻・䞇田：「低気圧空気中のインパルス放電 と陰極表面状態の影響」, 電気学会放電研資，ED-88-69（昭 63)

（8）大坪・山住・中原・䞇田・布施：「低気厈インパルス放電に おけるアーク開始時間と電極表面状態, 宮崎大学工学部研 究報告, 30,93 (昭 59 )

（9）暬田・大坪・芝・赫崎：「低気圧空気中に㧍ける正針インパ ルスフラッシオーバとその特性」, 電学論 A, 104, 585 (昭 5910)

（10）内山・渡辺・紀本：X 線マイクロアナライザ, p. 72；90（昭 54) 日刊工業新聞社

（11）辻・大坪・堅田・福山：「インパルス放電路の気体温度算定 々検討」, 宮崎大学工学部研究報告, 34,53 (昭 63)

（12）玉虫, 他編：理化学辞典, p. 966 (昭 46) 岩波曺店

（13）日本化学会：電子分光, p. $106 ； 223$ (昭 52) 学会出版セン 夕一

（14）染野·安盛：表面分析, p. 279；298（昭 54）講談社

（15）田部・清山・笛木：金属酸化物と複合酸化物， p. 423（昭 55） 講談社

（16），山住・大坪・永野・顀田：「低気圧空気中のインパルス放電 に用いた陰極表面の分析」, 宮崎大学工学部研究報告, 31, 103 (昭60)

（17）。山住・大坪・永野・筫田・磯野・光井：「低気圧空気中のイ ンパルス放電による突起表面の変化 I. 昭 59 電気関倸学会九 州支部連大, p. 228

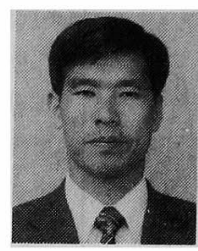

\section{大坪 昌 久 (正員)}

昭和 22 年 1 月 10 日生。 44 年 3 月宮崎大学工学部電気工学科卒業。 45 年 3 月同大学工学専攻科(電気工 学専攻)修了。同年 4 月宮崎大学工 学部電気工学科助手, 現在に至る。主として, 高電圧 現象の研究に従事。

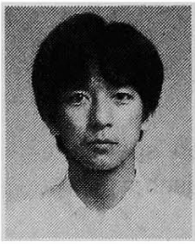

\section{山住薰（正員）}

昭和 35 年 6 月 2 日生。 59 年 3 月 宮崎大学大学院工学専攻科(電気工 学専攻)修了。同年 4 月日新電機 (株) 入社, その後, 日新八イボルテ ージ(株)に出向, 現在に至る。主として, 高電圧現象 の研究に従事。

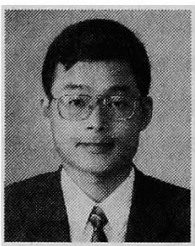

\section{竹 内 公 人 (正員)}

昭和 39 年 9 月 7 日生。平成元年 3 月宮崎大学大学院工学専攻科(電 気工学専攻) 修了。同年 4 月九州電 力(株)入社, 現在に至る。主とし て, 高電圧現象の研究に従事。

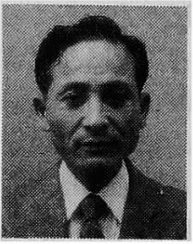

䞇 田寛（正員）

昭和 2 年 7 月 10 日生。 23 年 3 月 明治工業専門学校電気科卒業。36 年 7 月九州工業大学第二部電気工学 科助手。3 8 年 4 月宮崎大学工学部 電気工学科助手, 43 年 6 月同助教授, 61 年 1 月同教 授, 現在に至る。工学博士。主として, 高電圧現象の 研究に従事。 